Eixo Temático: Desenvolvimento de Estratégias Didáticas

\title{
ET-07-014 \\ EXPLANAÇÃO PARA ALUNOS DE ENSINO MÉDIO SOBRE A FORMAÇÃO DE SÍNDROMES GENÉTICAS
}

Denise de Queiroga Nascimento ${ }^{1 * *}$, Yorran Hardman Araujo Montenegro, Tafarel Fernandes Tavares de Melo

${ }^{1}$ Graduando em Ciências Biológicas, Universidade Estadual da Paraíba (UEPB). *E-mail: dennise.queiroga@gmail.com.

${ }^{2}$ Mestre em Ensino de Ciências (Biologia) - PPGECEM/UEPB.

http://dx.doi.org/10.21472/congrebio2016.et-07-014

\section{RESUMO}

O ensino da Biologia com enfoque na genética, principalmente no Ensino Médio, tem sido um desafio ao docente pelo fato de ser uma área bastante ampla e que exige um cuidado redobrado para a sua compreensão. Os princípios básicos sobre mutações e suas consequências, como parte importante da genética, necessitam também estar embasados no contexto escolar para que assim os alunos compreendam com mais eficácia a magnitude e a influência do material genético na vida cotidiana. Ao ver que a genética vem avançando constantemente e certos saberes precisam ser vistos no contexto escolar, este trabalho teve por objetivo mostrar a duas turmas de terceiro ano, da Escola Estadual de Ensino Fundamental e Médio Félix Araújo em Campina Grande-PB, por meio de metodologias simples e eficazes, a formação das síndromes genéticas e suas características, além de proporcionar também uma quebra paradigmas a respeito de pessoas portadoras de determinadas síndromes. De inicio para instigálos houve à elaboração de perguntas em uma dinâmica, na qual gerou discussões e debates com opiniões distintas e percepções individuais. Um questionário aplicado veio em seguida e apontou que $90 \%$ dos alunos conhecem a função do DNA e 53,30\% soube responder corretamente a constituição do DNA. 60\% afirmaram não ter visto algum exemplo de síndrome, mas $46,60 \%$ afirmaram que o erro no DNA gera uma síndrome e $66,70 \%$ soube responder como essa alteração ocorre. Entretanto, percebe-se que a contextualização e associação com a vida fora da sala de aula estavam ausentes e conceitos já determinados mecanicamente se fazia presente entre eles, sem compreender de fato o que aquilo representava. Posteriormente a ministração de três palestras foram esclarecedoras e gerou conhecimentos produtivos entre os estudantes. No fim, a produção de um cartaz informativo para expor sobre uma das síndromes ministradas mostrou eficácia na absorção de conhecimento e a metodologia dinamizada fez o alunado enxergar a genética de uma maneira mais fácil, quebrando os paradigmas que tinham entre eles a respeito das síndromes e souberam responder conscientes daquilo que lhes era perguntado.

Palavras-chave: Genética; Metodologia; Aprendizagem.

\section{INTRODUÇÃO}

O Ensino da Biologia é bastante amplo, especialmente devido a seu arsenal de conteúdos básicos presentes no âmbito educacional básico. O enfoque na genética exige um cuidado maior devido aos seus gradativos avanços. Por esse motivo, os estudantes podem se apropriar de saberes científicos através de metodologias eficazes e materiais precisos. Mas, um dos desafios enfrentados na sala de aula, segundo Vilela (2007) é associar os conteúdos ministrados com a realidade na qual os estudantes estão inseridos. Na concepção de Martins, 
(2010) vários alunos, principalmente aqueles que cursam o Ensino Médio, não conseguem fazer associações entre conceitos da genética como: alelos, genes, cromatina e cromossomo. Não ter o conhecimento de que estes termos estão associados à molécula de DNA e nem à prática metodológica adequada, acaba tornando-se difícil e desinteressante sua abordagem educacional (MOURA et al., 2013).

Os princípios básicos sobre mutações e suas conseqüências necessitam também serem abordadas no contexto escolar para que os alunos compreendam com mais eficácia a magnitude e a influência do material genético na vida cotidiana. muitos podem ter o conhecimento de que o DNA armazena informações para a formação de um organismo, , mas poucos conhecem a fundo que síndromes e determinadas anomalias podem ser oriundas de um erro genético (MOURA et al., 2013). Embora o tamanho do genoma humano seja bastante significativa, quaisquer alterações em um dos pares de bases de nucleotídeos ou em uma própria estrutura dos seus cromossomos podem resultar em um mau funcionamento fisiológico (GLANCY, 2008). Essas alterações, denominada de mutação, podem ocorrer em um determinado trecho de DNA ou podem ser em nível de cromossomo.

Visto que é importante a compreensão dos aspectos genéticos, como no caso das síndromes genéticas, é indispensável o auxilio de metodologias simples e didáticas como a educação por recursos áudio-visuais, dentro da sala de aula para expor o conteúdo e torná-lo fácil e interessante de se aprender.

\section{OBJETIVOS}

Repassar para alunos de terceiro ano da Escola Estadual e de Ensino Fundamental e Médio Félix Araújo, localizada em Campina Grande-PB as características genotípicas e fenotípicas das síndromes genéticas mais conhecidas de maneira prático-didática por meio de palestras e oficina ministradas na escola.

\section{METODOLOGIA}

O modelo do trabalho é quali-quantitativo.

O trabalho iniciou com a aplicação de um questionário contendo cinco questões objetivas e de múltipla escolha na qual abordava conceitos básicos de genética e as síndromes ocasionadas por um erro no material genético, como: 1) Qual a função do material genético; 2) Qual a constituição do DNA; 3) Qual a consequência de um erro nesse material genético. Bem como, sobre assuntos co-relacionados, nos introduzindo ao conhecimento a cerca das síndromes genéticas, onde foi perguntado no mesmo questionário se os mesmos já haviam ouvido falar nelas e se saberiam o que ocasionava uma síndrome genética.

Posteriormente foram desenvolvidas três palestras na escola a fim de explanar o assunto para o público alvo: duas turmas de $3^{\circ}$ ano do ensino médio da Escola Estadual de Ensino Fundamental e Médio Félix Araújo. Nessas respectivas palestras foram abordados aspectos genéticos primeiramente, como por exemplo, a função do DNA, formação dos cromossomos, divisão celular, em seguida, na segunda palestra, como ocorrem às mutações que levam a formação de síndromes e na terceira palestra, foi abordando as várias síndromes que são ocasionadas por alterações genéticas, como a síndrome Chi-du-chat, síndrome de Tuner e a síndrome de Klinefelter e mais detalhadamente a síndrome de Down.

Intercalado com as palestras, foram realizadas dinâmicas educativas a fim de explorar o conhecimento prévio do alunado, e para finalização do trabalho, houve o desenvolvimento de um cartaz informativo feito pelos alunos sobre alguma síndrome genética vista com o intuito de por em prática o que foi aprendido no decorrer das palestras.

O programa utilizado na análise do questionário foi o EXCEL 2007, disponível no Microsoft Office. Os dados puderam ser agrupados em dados estatísticos, em porcentagens, para a melhor visualização destes, desenvolvendo uma discussão mais aprazível e eficiente. Foi 
dividio o número de questionários em cada resposta pelo número total e o resultado por fim foi multiplicado por 100 (cem), transformando-o em porcentagem.

\section{RESULTADOS E DISCUSSÃO}

Nos primeiros contatos foi possível identificar algumas dificuldades na compreensão dos aspectos voltados para as síndromes. Essa detecção se deu por uma dinâmica inicial, onde os alunos de duas turmas contendo 30 alunos formaram um círculo na sala precisavam pegar um dos papéis que estavam contidos em um recipiente. Dentro desses papéis havia perguntas informais que de modo geral buscava descobrir o que os estudantes pensavam e sabia a cerca de formação das síndromes, como os indivíduos com síndromes se comportavam, como elas adquiriam essas alterações e quais as consequências e limitações estas poderiam ter. Opiniões distintas foram levantadas e poucos sabiam responder e de maneira superficial sobre questões genotípicas dessas síndromes. Muitos enfatizaram que se tratava de um mau funcionamento genético e por isso seria um tipo de doença, mas as opiniões contrárias argumentam que para ser uma doença teria que ser infecciosa e um erro a nível genético não poderia ser denominado como síndrome. Outro ponto relevante nessa discussão foi que pessoas portadoras de síndromes são eternas crianças e não se desenvolvem ao longo do tempo. Uma grande parte dos estudantes afirmou que a síndrome genética pode limitar sua vivência e desenvolvimento social. Mas sabese que existem síndromes, como a síndrome de Down, que podem ser encontradas em graus diferentes da doença, sendo uns mais desenvolvidos que outros. No encontro seguinte com as turmas, foi aplicado um questionário contendo cinco questões de múltipla escolha para. A finalidade para tal aplicação de questões é conhecer o que os alunos sabiam a cerca de conceitos básicos da genética como também as síndromes. Primeiramente, perguntava-se qual a função do material genético. As respostas estão representadas no Gráfico 1.

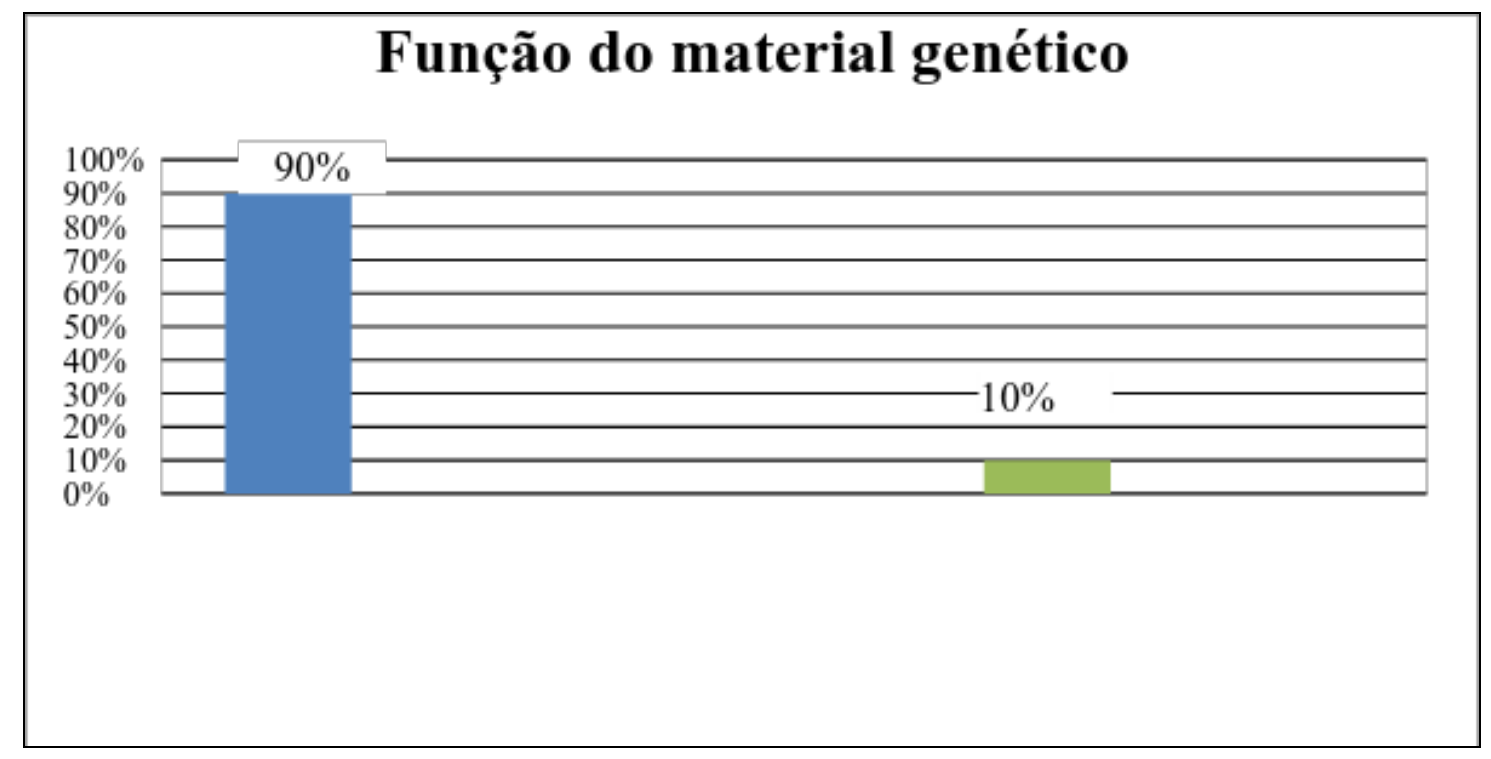

Gráfico 1. Resposta dos alunos quanto à função do material genético.

A maioria representada por $90 \%$ afirmaram que o material genético tem a função de guardar e transmitir informações. Esses dados mostram que os alunos conhecem a função principal do DNA e que o assunto não é desconhecido por eles. Além disso, é de extrema importância o saber desses conceitos por esclarecer todos os outros aspectos que abrangem o material genético. Vale ressaltar que os estudantes podem tanto aprender ou até mesmo apenas 
memorizar esses conceitos básicos por meios de livros didáticos, instrumento base para muitos na sala de aula, como também ouvir os professores descreverem a principal função do DNA que rege todos os outros aspectos genéticos.

Posteriormente foi perguntada de que é constituído o DNA. As respostas estão explícitas no Gráfico 2.

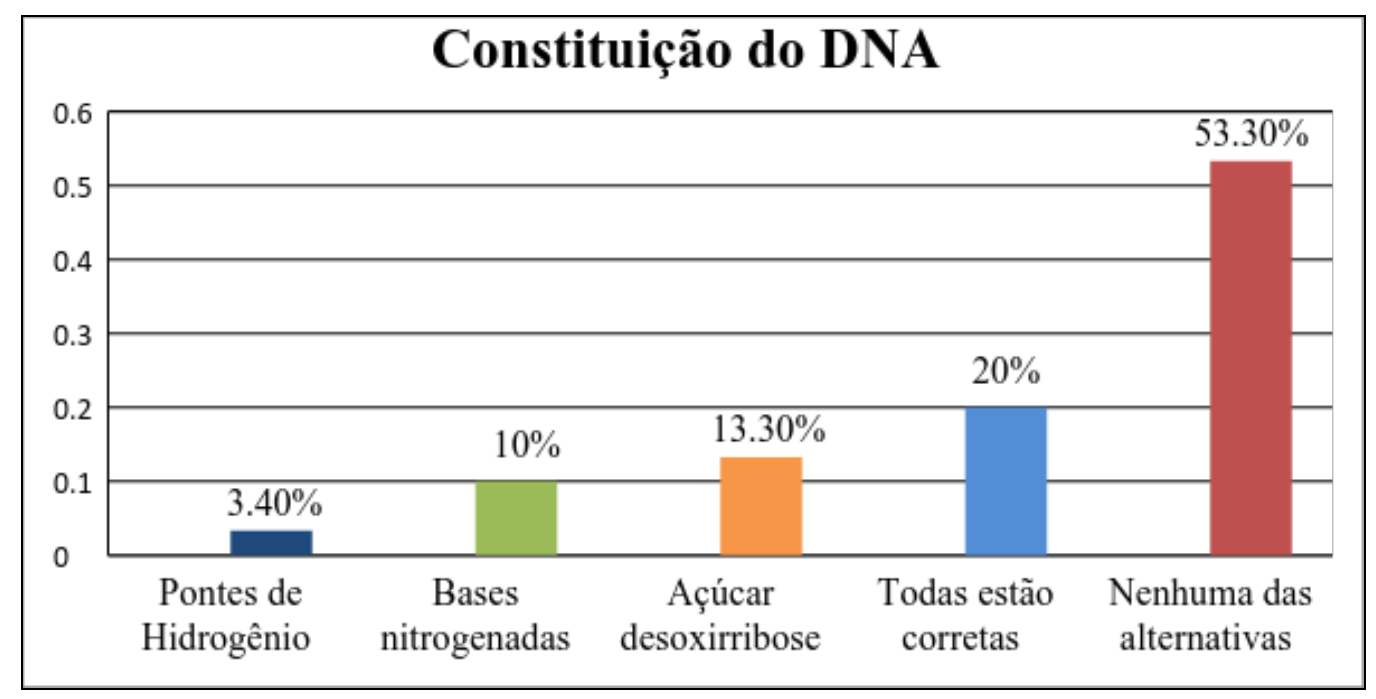

Gráfico 2. Respostas dos alunos quanto à constituição do DNA.

Verifica-se que 53,30\% dos alunos responderam que nenhuma das alternativas estão corretas. Porém, a molécula de DNA é constituída por todas as alternativas anteriores e dessa forma todas estão corretas, mas somente $20 \%$ responderam-na. Esses dados demonstram que não há uma associação de conceito com a estrutura em si da molécula. Alguns poucos estudos realizados no Brasil sobre esse aspecto, mostrou que temas gerais e específicos relacionados a genética são mal interpretados pelos estudantes. Ainda também, a questão da não associação da função do material genético com sua estrutura revela a falta de contextualização dos conteúdos.

Para enfim conhecer mais especificamente o que estes alunos sabiam sobre as alterações genéticas e então formação de mutações, as três últimas perguntas foram: Quais seriam as consequências geradas caso ocorressem um erro no DNA; Já ouviram falar alguma síndrome genética; O que leva a ocasionar uma síndrome genética. Todos os resultados dessas perguntas estão reveladas nos Gráficos 3, 4 e 5. 


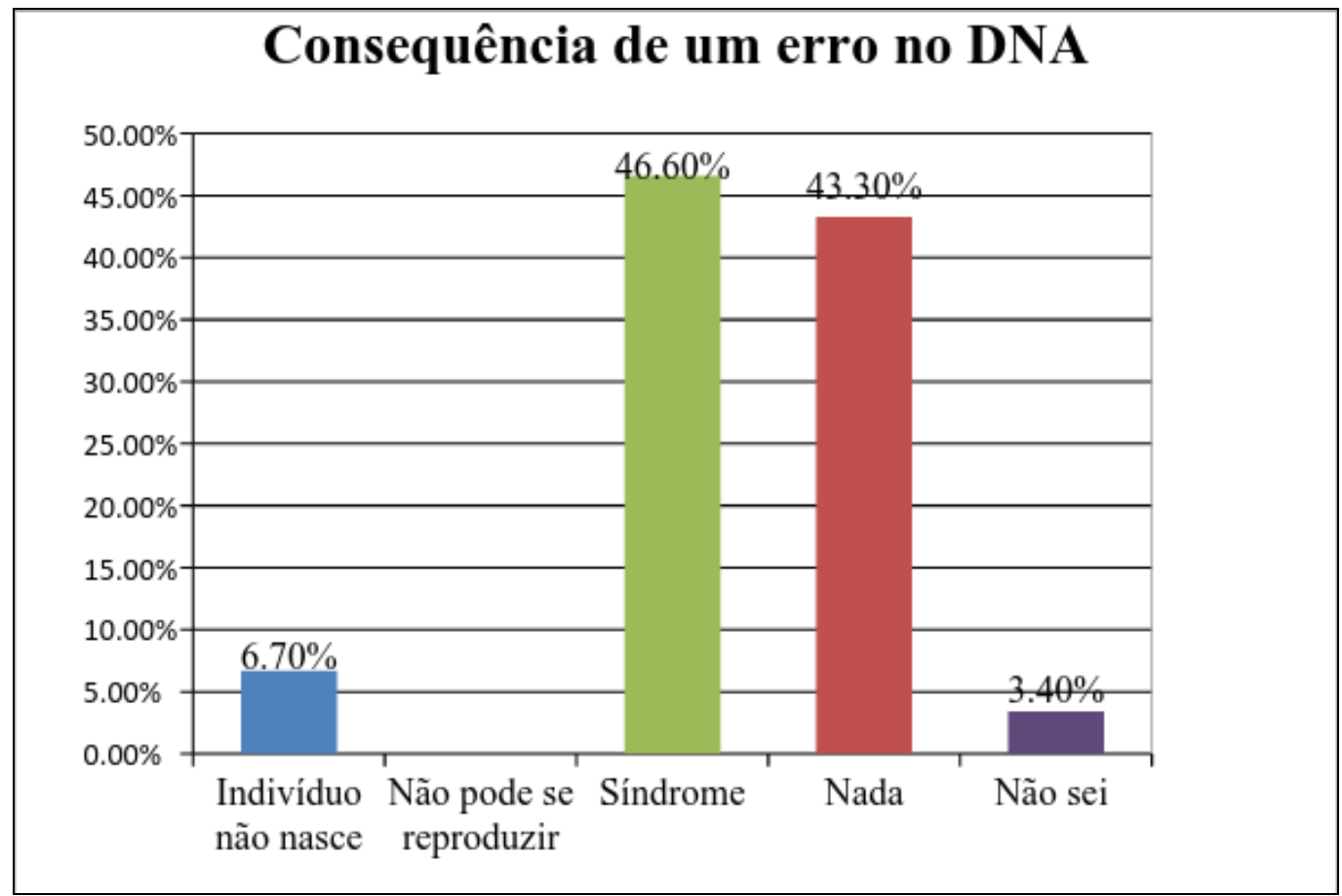

Gráfico 3. Respostas dos alunos quanto a conseqüência de um erro no DNA.

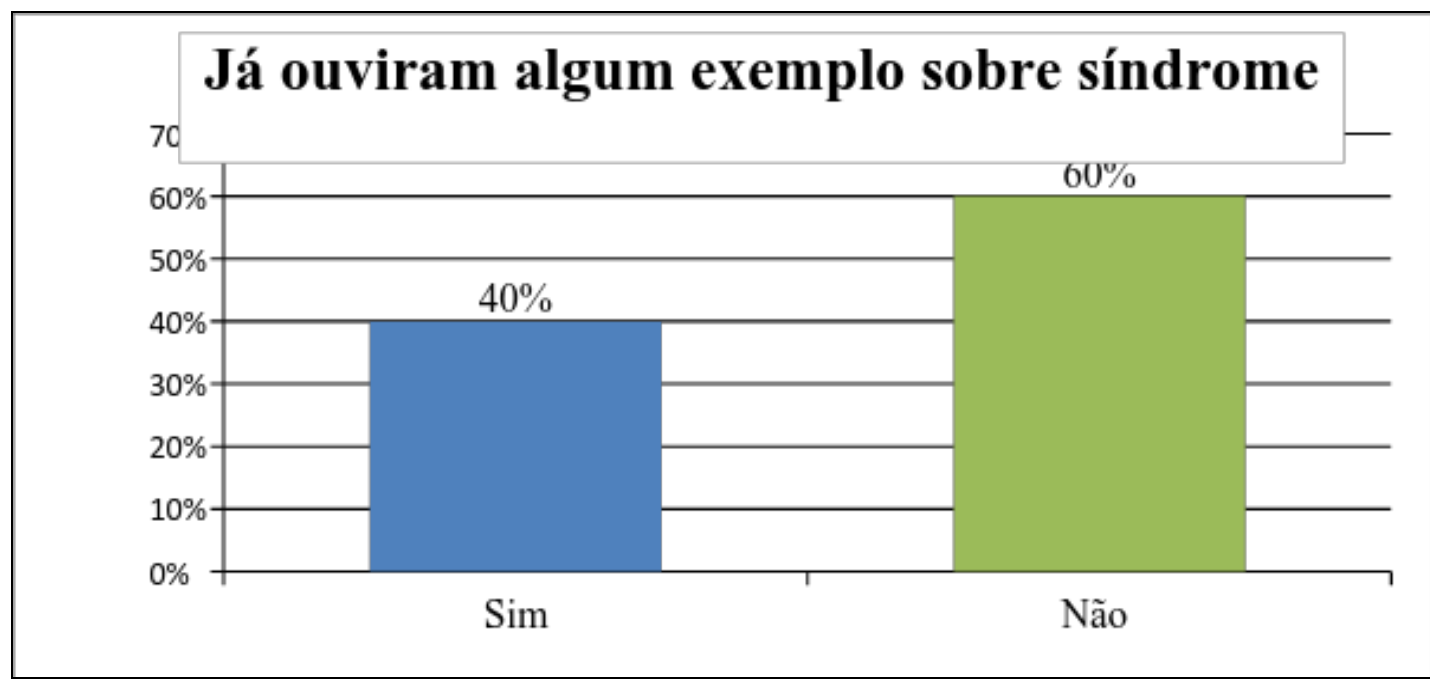

Gráfico 4. Respostas dos alunos quanto a ouvir algum exemplo sobre síndrome genética. 


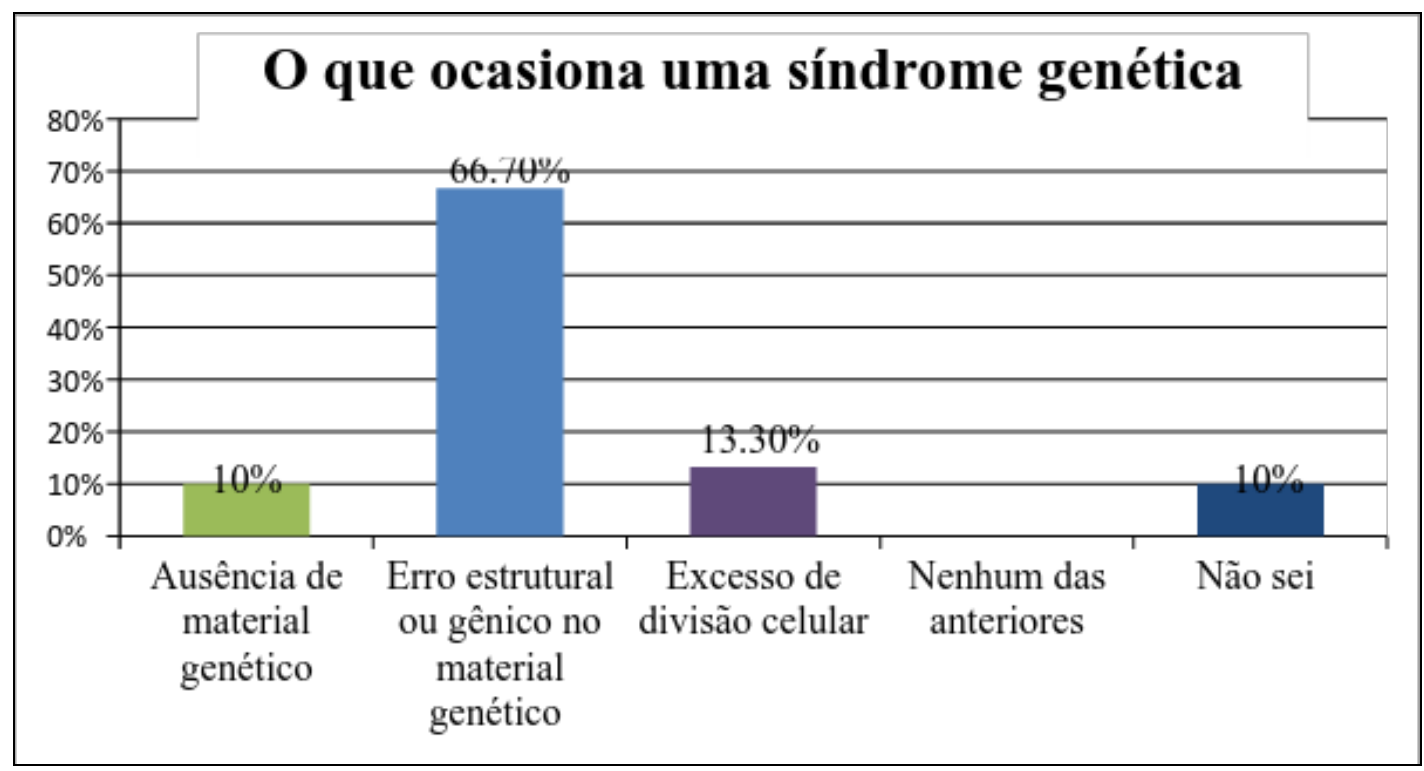

Gráfico 5. Respostas dos alunos quanto à causa de uma síndrome genética.

Os dados em destaque no gráfico 1 foi a divisão entre 43,30\% dos alunos ao afirmarem que nada acontece quando um erro genético ocorre e de semelhante porcentagem, 46,60\% disseram que tal acontecimento gera uma síndrome. Outro dado que afirma essas indagações foi $40 \%$ dos participantes afirmarem ter ouvido sobre alguma síndrome genética e $60 \%$ não terem visto exemplos. No gráfico 3 , quando perguntado sobre o que ocasiona uma síndrome genética o dado relevante é que 66,70\% conhece que o erro cromossômico ou gênico do DNA explica esse efeito. Mas, avaliando esses dados verifica-se que há uma diferença entre definição do que é e identificação na integra do que foi visto em sala. Essas respostas podem ser explicadas por dois fatores: falta de associação do assunto ministrado em sala de aula com a realidade fora dela e conhecimento apenas superficial do conteúdo. Atualmente a mídia tem propagado inúmeros avanços científicos e grande parte destes avanços está aliada a genética. Isso tem despertado interesse nos estudantes, mas tanto os professores como os alunos tem dificuldade de contextualizar os conteúdos de livros didáticos com a realidade que se encontram inseridos. Dessa forma os alunos aprendem de maneira mecanizada e não conectam o conhecimento com os fatos noticiados.

Mediante essas questões de ensino e aprendizagem, o uso de metodologias simples e didáticas foi desenvolvido no decorrer desse trabalho por saber que estas são eficazes no processo de aquisição de conhecimento. Para esclarecer as questões levantadas, as três palestras, cada uma ministrada semanalmente por meio de slides didáticos, objetivos e ilustrativos, foi mostrada conceitos básicos do DNA, organizações da célula para a divisão celular, formação dos cromossomos e como as síndromes podem ser ocasionadas, destacando as principais características e o comportamento de indivíduos portadores das síndromes. Ao término dessas palestras houve esclarecimentos, discussões, relatos de casos, curiosidades e retiradas de muitos pensamentos falsos a cerca das pessoas portadoras de síndromes. Dentre essas coisas, a ideia que um erro no material genético não causa nada e que as síndromes estavam relacionadas a infecções e não a alterações foi retirada dos alunos. A síndrome de Down foi à síndrome mais citada no meio deles por ser mais comum do que as demais mencionadas.

Para descobrir mais esclarecimentos genéticos e aprendizagem positiva por meio das exposições dos assuntos nas palestras, a mesma dinâmica desenvolvida no inicio do trabalho foi repetida. Agora, ao pegarem os papéis passaram a responder corretamente e explicar a nível genético como elas correm. Visto isso, uma oficina didática para finalização do trabalho foi elaborada por eles. Equipes foram divididas e materiais como jornais, revistas, cartazes, lápis e 
afins foram distribuídos para a elaboração de um cartaz informativo sobre a síndrome de Down. Nesse cartaz a equipe teve que demonstrar seus conhecimentos sobre a doença e serem bastante criativos para chamar atenção de outras pessoas a fim de conhecer mais sobre a síndrome. Vários modelos foram elaborados e discussões estimuladas entre a equipe para abordar 0 assunto estudado (Figura 1 e Figura 2).

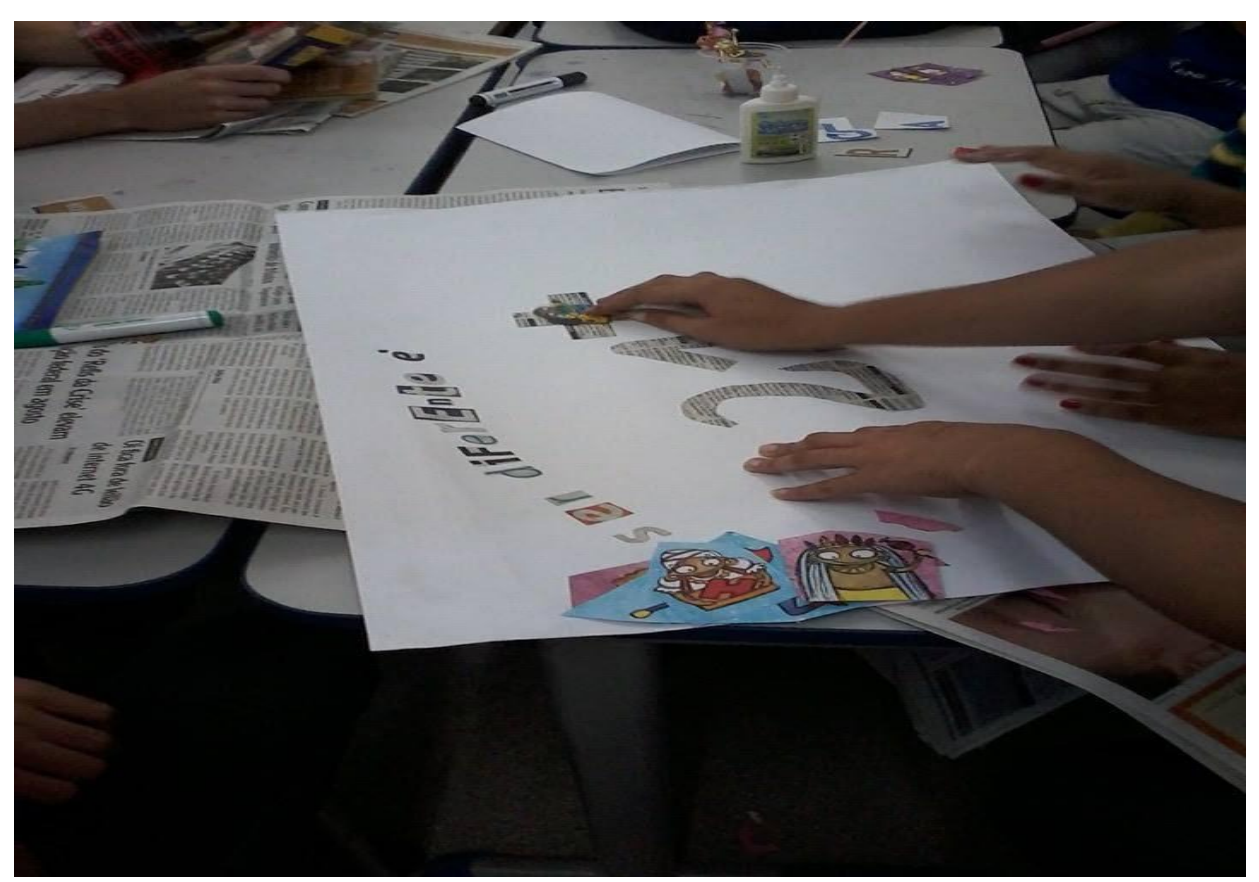

Fígura 1. Construção do cartaz informativo sobre a síndrome de Down.

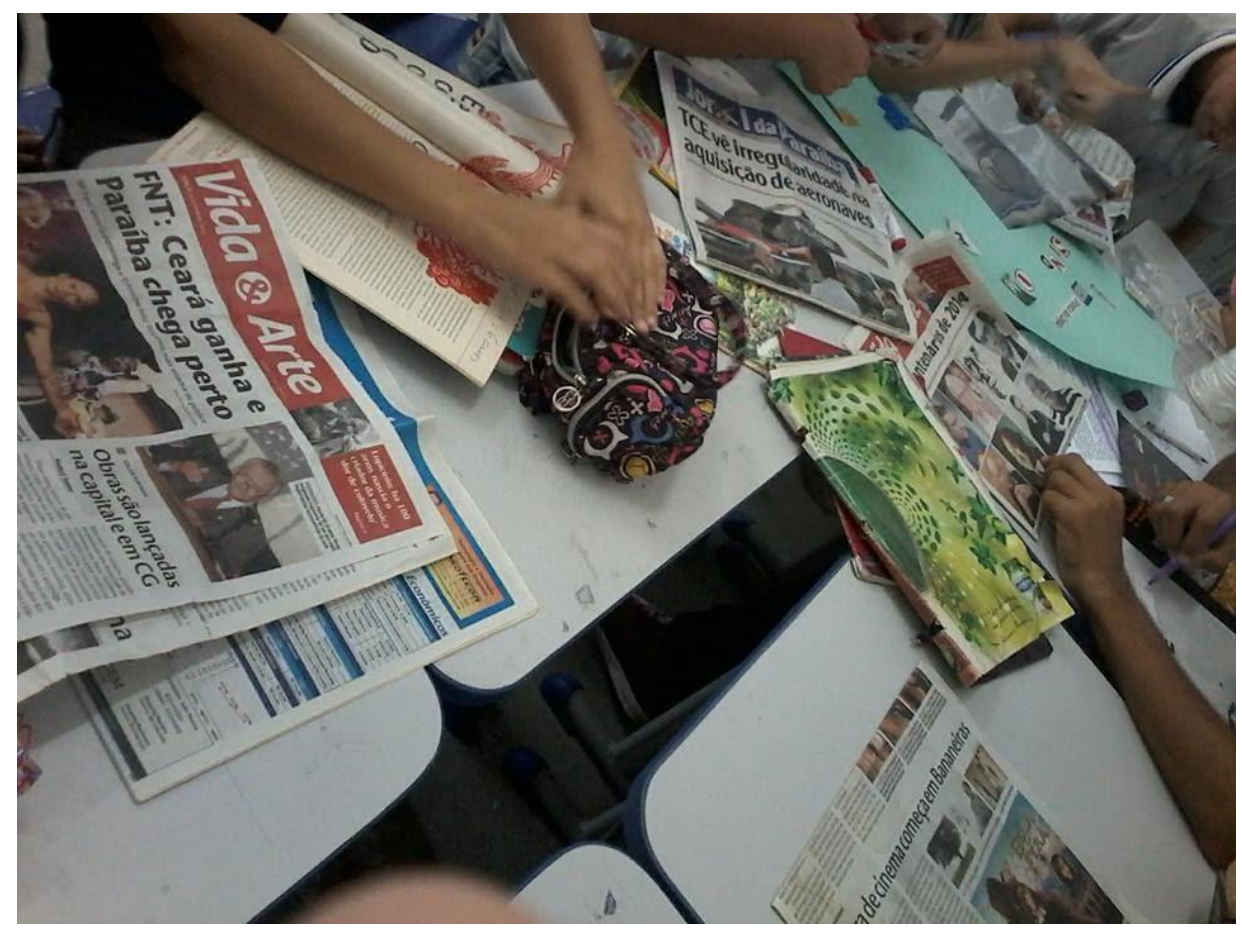

Figura 2. Alunos elaborando o cartaz informativo. 
Dessa forma, com as atividades concluídas, percebemos o tamanho interesse pelos alunos quanto à Genética e a importância de desenvolver metodologias diferenciadas para garantir um aprendizado significativo. Esses dados confirmam o que as literaturas falam sobre o uso desses métodos, para Moura et al. (2013) é necessário que os professores tenham a disposição recursos didáticos que propiciem a relação da teoria com a prática e a falta dessas metodologias podem colaborar para uma má formação de conceitos e incompreensão de conteúdos. Diversas pesquisas que analisam o uso de metodologia prática, afirma que técnicas pedagógicas contribuem no processo de ensino e aprendizagem e assume a dimensão de conjunto de dispositivos didáticos pedagógicos para mediar a construção do conhecimento e atingir os objetivos específicos de determinada aula.

\section{CONCLUSÃO}

Com a aplicação desse trabalho nas duas turmas de terceiro ano do ensino médio foi possível ver que uma metodologia diferenciada é bastante significativa na absorção de conhecimento. O desenvolvimento de atividades diferenciadas dentro da sala de aula estimula os alunos a estudarem, a buscarem informações e gerarem curiosidades. Mediante o uso de métodos dinâmicos e discursivos foi perceptível a mudança de pensamento e adesão de conhecimento por parte dos alunos dentro da sala de aula. Paradigmas a cerca das síndromes, principalmente da síndrome de Down, foram quebrados e uma nova visão sobre genética foi gerada em meio a debates e esclarecimentos, bem como na elaboração do material prático sobre o assunto visto no decorrer das palestras.

\section{REFERÊNCIAS}

GLANCY, S. Genetic mutation: a sigle base change can create a devastating genetic disorder or a beneficial adaptation, or it might have no effect. How do mutation happen, and how do they influence the future of a species? Nature Education, v. 1, nº 1, p. 187, 2008.

MARTINS, I. Clonagem na sala de aula: um exemplo de uso da didática de um texto de divulgação científica. Rio de Janeiro: UFRJ, 2010.

MOURA, J.; DEUS, M. S. M.; GONÇALVES, N. M. N.; PERON, A. A Biologia/Genética: o ensino da Biologia com enfoque a Genética, das escolas públicas no Brasil - breve relato e reflexão. Semina: Ciências Biológicas e da Saúde, v. 2, no 34, p. 167-174, 2013. http://dx.doi.org/10.5433/1679-0367.2013v34n2p167

VILELA, M. R. A., A produção de atividades experimentais em genética no Ensino Médio. Belo Horizonte: Universidade Federal de Minas Gerais, 2007. (Monografia de Especialização). 